\title{
Robert J. Coady's The Soil and Marcel Duchamp's Fountain: Taste, Nationalism, Capitalism, and New York Dada
}

\section{Menno Hubregtse}

Volume 34, numéro 2, 2009

URI : https://id.erudit.org/iderudit/1069487ar

DOI : https://doi.org/10.7202/1069487ar

\section{Aller au sommaire du numéro}

\section{Éditeur(s)}

UAAC-AAUC (University Art Association of Canada | Association d'art des universités du Canada)

\section{ISSN}

0315-9906 (imprimé)

1918-4778 (numérique)

Découvrir la revue

\section{Citer cet article}

Hubregtse, M. (2009). Robert J. Coady's The Soil and Marcel Duchamp's Fountain: Taste, Nationalism, Capitalism, and New York Dada. RACAR : Revue d'art canadienne / Canadian Art Review, 34(2), 28-42.

https://doi.org/10.7202/1069487ar

\section{Résumé de l'article}

Cet article émet l'hypothèse que Marcel Duchamp aurait choisi Fontain comme readymade parce cet objet brocardait l'appel de Robert J. Coady en faveur de l'art américain indigène. Coady, qui voyait dans le paysage industriel américain en effervescence une véritable source d'inspiration pour l'art de son pays, a largement fait état de son programme nationaliste dans sa revue The Soil. Fountain, un urinoir en porcelaine présenté au Salon des indépendants en avril 1917, semble se moquer de cette glorification des objets industriels qui pousse Coady à voir en ceux-ci d'authentiques formes artistiques américaines. Dans le même esprit, plusieurs articles de la revue The Blind Man publiée par Duchamp, Henri-Pierre Roché et Béatrice Wood parodient les déclarations patriotiques émises par Coady dans sa revue The Soil. Le présent article explique également pourquoi Coady n'a pas fait partie du mouvement New York Dada. Il y a été associé par erreur parce qu'il critiquait ouvertement l'art moderne américain. Ses prises de position contrastaient cependant avec les traits typiques du mouvement Dada : la rébellion contre le capitalisme, le patriotisme et toutes les traditions et institutions établies du monde de l'art.
Tous droits réservés (C UAAC-AAUC (University Art Association of Canada | Association d'art des universités du Canada), 2009
Ce document est protégé par la loi sur le droit d'auteur. L'utilisation des services d'Érudit (y compris la reproduction) est assujettie à sa politique d'utilisation que vous pouvez consulter en ligne.

https://apropos.erudit.org/fr/usagers/politique-dutilisation/ 


\title{
Robert J. Coady's The Soil and Marcel Duchamp's Fountain: Taste, Nationalism, Capitalism, and New York Dada
}

\author{
Menno Hubregtse, University of Victoria
}

\begin{abstract}
Résumé
Cet article émet l'hypothèse que Marcel Duchamp aurait choisı Fontain comme readymade parce cet objet brocardait l'appel de Robert J. Coady en faveur de l'art américain indigène. Coady, qui voyait dans le paysage industriel américaın en effervescence une véritable source d'inspiration pour l'art de son pays, a largement fait état de son programme nationaliste dans sa revue The Soll. Fountain, un urinoir en porcelaine présenté au Salon des indépendants en avril 1917, semble se moquer de cette glorification des objets industriels qui pousse Coady à voir en ceux-ci d'authentiques formes artistiques américaines. Dans le même esprit, plusieurs articles de la revue The Blind Man publiée par Duchamp. Henri-Pierre Roché et Béatrice Wood parodient les déclarations patriotiques émises par Coady dans sa revue The Soil. Le présent article explique également pourquoi Coady n'a pas fait partie du mouvement New York Dada. ll y a été associé par erreur parce qu'il critiquait ouvertement l'art moderne américain. Ses prises de position contrastaient cependant avec les traits typiques du mouvement Dada: la rébellion contre le capitalisme, le patriotisme et toutes les traditions et institutions établies du monde de l'art.
\end{abstract}

$\mathrm{M}$ arcel Duchamp's Fountain is perhaps the most notorious and perplexing art object of the twenticth century. The submission of Fountain to the Independents Exhibition of April 1917 is considered a significant cvent in New York Dada's history. The white porcclain urinal arrived mysteriously at the exhibition, signed with the pscudonym R. Mutt. The urinal is one of Duchamp's readymades-everyday, manufactured objects "selected" by Iuchamp that challenged concepts of aesthetics and taste in arc. But the reasons why Fountain was sclected as an art object have remained obscure. While much has becn written about Fountain, one detail that requires further attention is its relationship with Robert J. Coady's publication The Soil. Coady wrote a patriotic manifesto in The Soil that called for an indigenous American art unscathed by the traditions of Europe. He disparaged American modern art and traditional academic art--both influenced by European predecessors-and promoted a homegrown American modern art, which he proposed should include industrial machinery of the nation's growing capitalist entcrprises. Coady has been crroneously paired with New York Dada because of his aggressive attack on the state of modern art in America. I will discuss how Coady's statements and actions contrast with the anti-capitalist, anti-nationalist, anti-patriotic, and anti-art characteristics of New York Dada, and how Duchamp may have selected Iountain as a rcadymade because it cunningly satirizcd Coady's nationalistic agenda, which championed American industrial machinery as art.

\section{Robert J. Coady}

Robert J. Coaldy was an art dealer who promoted the avantgarde in America, but was also an outspoken critic of the influence of European modern art on American art in the early twentieth century.' He owned two galleries in New York between 1914 and 1919. In the spring of 1914, he and the artist Michael Brenner established the Washington Square Gallery, which was located in Greenwich Villagc. Brenner's role was to find artworks and to ncgotiate contracts with arc dealers in Europe. Coady's role was to manage the operations at the gallery in New York. The gallery exhibited work by Juan Gris, Andre Dérain, Henri Rousscau, Pablo Picasso, Georges Braque, Henri Matisse, and Diego Riviera, as well as African and South Sea sculpture. Coady's side projects included selling Daniel-Henry Kahnweiler's photographs of modern art, targeting art students as the primary market. ${ }^{2}$ In late 1916 , he relocated the gallery to Fifth Avenuc and renamed it the Coady Gallery.

His most fascinating contribution to modern American art is The Soil, a magazinc published between December 1916 and July 1917. This journal challenged high art and promoted Coady's concepts for a national art. In his January 1917 issue, he declared, "By American Art I mean the aesthetic product of the human beings living on and producing from the soil of thesc United States. By American Art I mean an American contribution to art." 3 He belicved that the "aestheric product[s]" were already in place and that the art world had not yet recognized them as true American artworks. He appended an extensive list of various American art objects in his first issue of The Soil. The items were predominatcly industrial machines and products of capitalist America: "...The Cement Mixers, the Uneeda Biscuit Building. The Pulleys and Hoists. The Buckers and Pumps and the Keyseaters. The Cranes, the Plows, the Drills, the Morors, the Thrashers, the Derricks, Steam Hammers, Stone Crushers...."4

Coady visually expressed his fascination with industrial machinery in a photo-essay, "Moving Sculpture Series," printed in the January 1917 issue. 5 The photo-essay referenced the following machines: a Sellers Ten Ton Swinging Jib Crane, an Industrial Works 120-Ton Crane, a Locomotive No. 40000, an American Forging Press, an Erie Hammer, and a Chambersburg Steam Hammer. In the same issue he juxtaposed a photograph of the Maine Memorial and a photograph of the Chambersburg Double Frame Steam Hammer (fig. 1). ${ }^{6}$ Below the diptych he asked, "Which is the Monument?" 'This was a clever compari- 


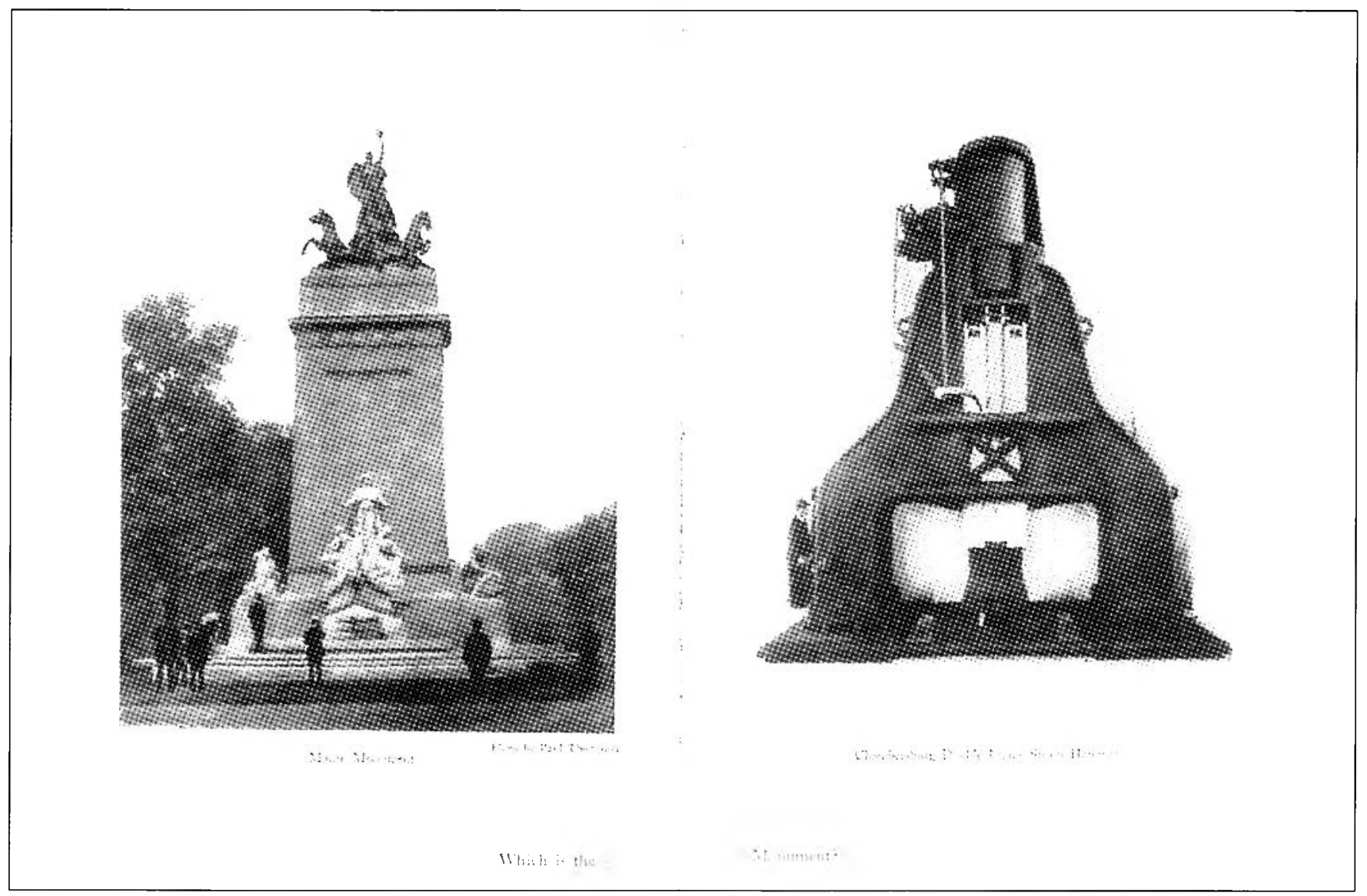

Figure 1. "Which is the Monument"" in The Soil I. 2 (January 1917).

son of a Beaux-Arts monument that commemorated the Mainc, a battlcship sunk in the Spanish-American War, with Coady's all-Amcrican steam-hammer-an object unscathed by European traditions and influences.

Coady believed that industrial products embodied the spirit of America and had far greater significance as a national art form than the art bcing produced and promoted by artists and critics trained at the various academies throughout America. 'The anti-academic art created by New York's avant-gardc artists did not receive his stamp of approval either. He criticized and satirized the thorctical aspects of modern art, stating, "[American art is] not in the fifth dimension or the three hundred and sixty-first degree....It can't comc from reducing drawing to angles and curves, or separating color from form. It can't come from free freedom or political paint....It can't come from theory in place of taste." 7

Coady wanted American art to be free from all the "isms" that came from Europe and to embrace everything associatcd with American life. His notion of a non-theoretical American art was expressed in the photograph of cowboy Jess Stahl that he published The Soil. The photo captured the stampeder in action on his bronco (fig. 2) and had the caption: "JESS STAHL. He has no ism to guide him." 8 For Coady the stampede was "onc of the most remarkable exhibitions of art." 9 Boxing was covered in The Soil as wcll; Coady included a number of articles on the sport and various photographs of prizefighters. ${ }^{10}$

On 20 March 1916, Coady sent photographs of two locomotives to John Quinn to foster support for his brand of American modernism." Quinn, who had purchased a number of artworks from Coady's gallery, was a lawyer who would later defend the Little Review, published by Margaret C. Anderson in New York, from prosecution for printing James Joyce's Ulysses. 'Two days after receiving the photos of the railroad cngines, he replied, "I should hardly call them 'American Art' any more than I would call a beautifully designed yacht 'art."'12 Quinn's uncnthusiastic response did not discourage Coady; a half year later he reproduced the photos (fig. 3) in his first issuc of The Soil. 


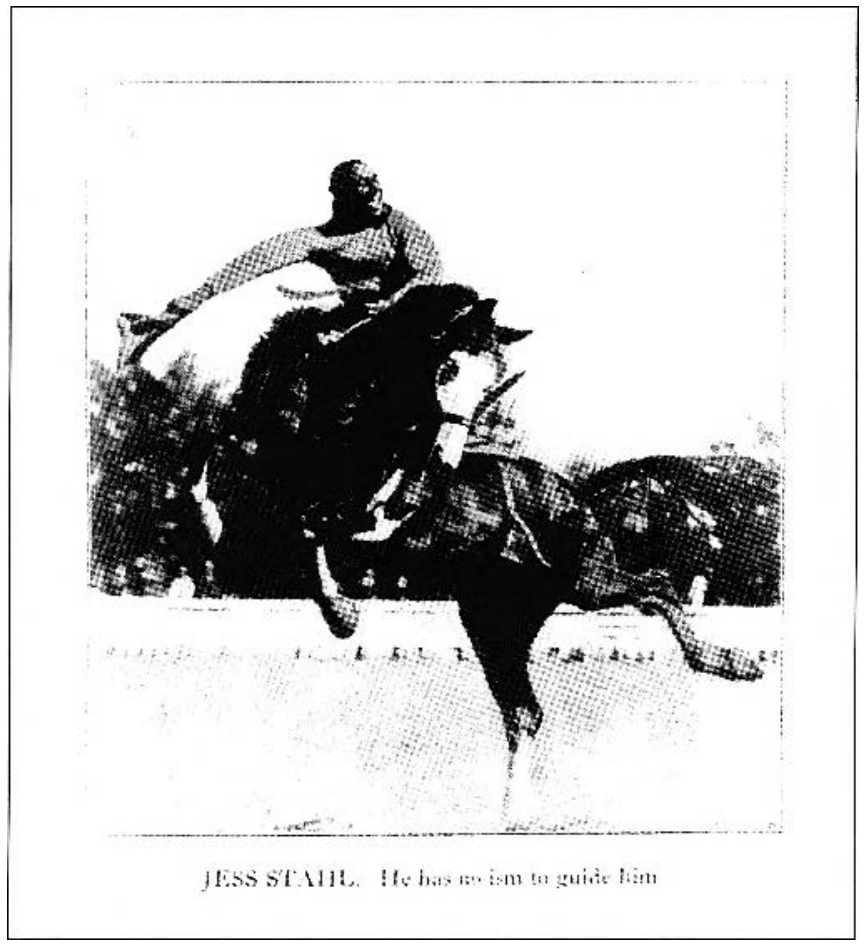

Figure 2. Photograph of Jess Stahl in The Soil I, I (December 1916).
Eight days before contacting Quinn, Coady had disseminated his campaign for a unique form of modern art in the New York Sun. In an article dedicated to the upcoming Forum Exhibition, the newspaper included a segment by Coady that criticized the motives for the exhibition. ${ }^{13}$ Intended as a response to the European dominated Armory Show of 1913, the exhibition was restricted to American artists and was meant to illustrate artistic developments that were occurring within the country. The exhibition's object was "to bring serious, deserving painters in direct contact with the public without a commercial intermediary." The exhibition's committee members, Willard Huntington Wright, Alfred Stieglitz, Robert Henri, Dr. Christian Brinton, Dr. John Weichsel, and W.H. de B. Nelson, declared that they had "no financial interest whatever in this exhibition" and that their services "have been given free." 14 In the New York Sun article on March 12, Coady questioned the commitrce's selection criteria: how could the art hold any value with respect to the American nationality, and how could the Forum exhibition committee guarantee that the paintings exhibited would "be worth the same price" in five years time? The newspaper printed Willard Huntington Wright's response to Coady in the same article. He replied to each of Coady's questions, but his

Figure 2. Photograph of Jess Stahl in The Soil I, I (December 1916).

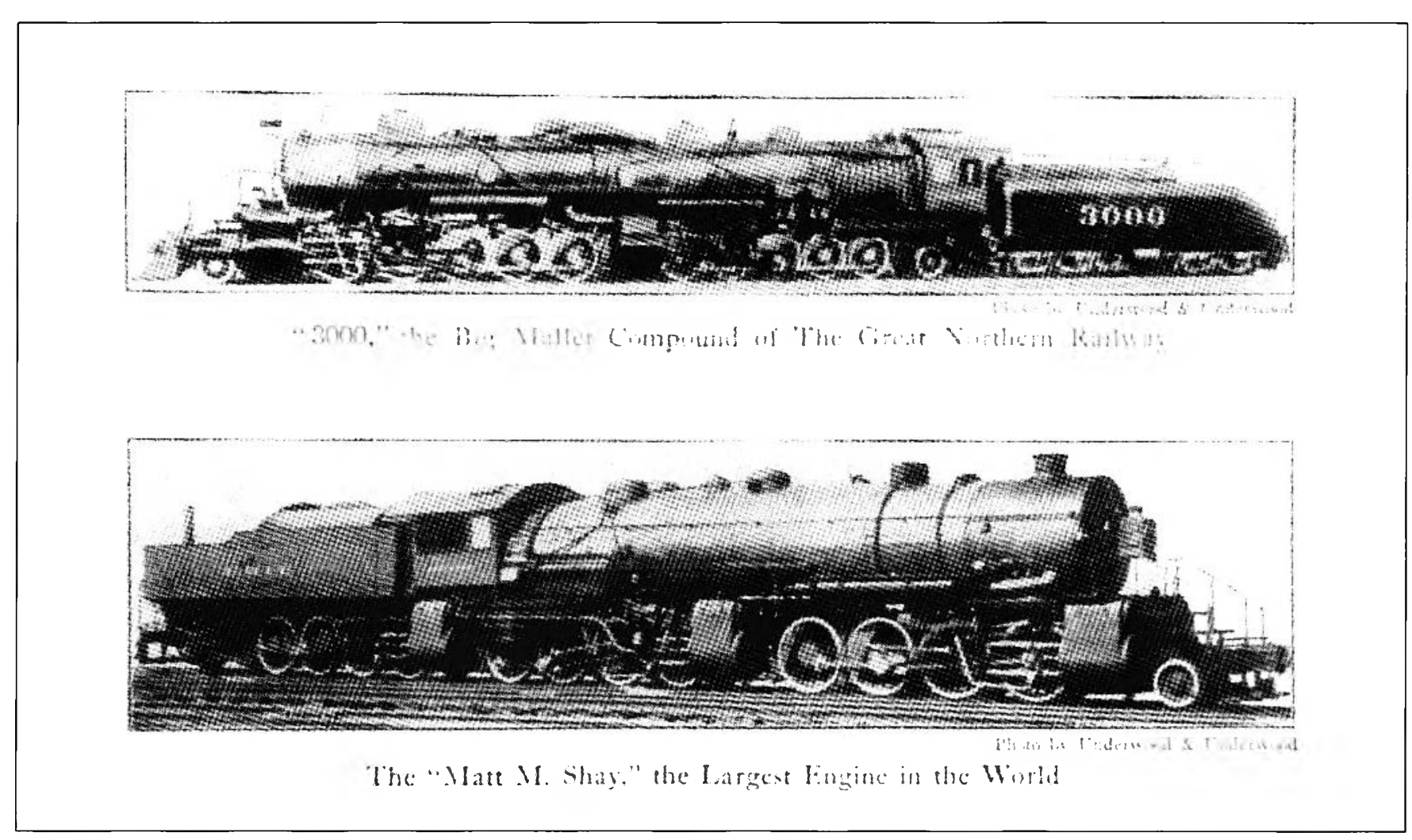

Figure 3. Photographs of railroad engines in The Soil I. I (December 1916). 


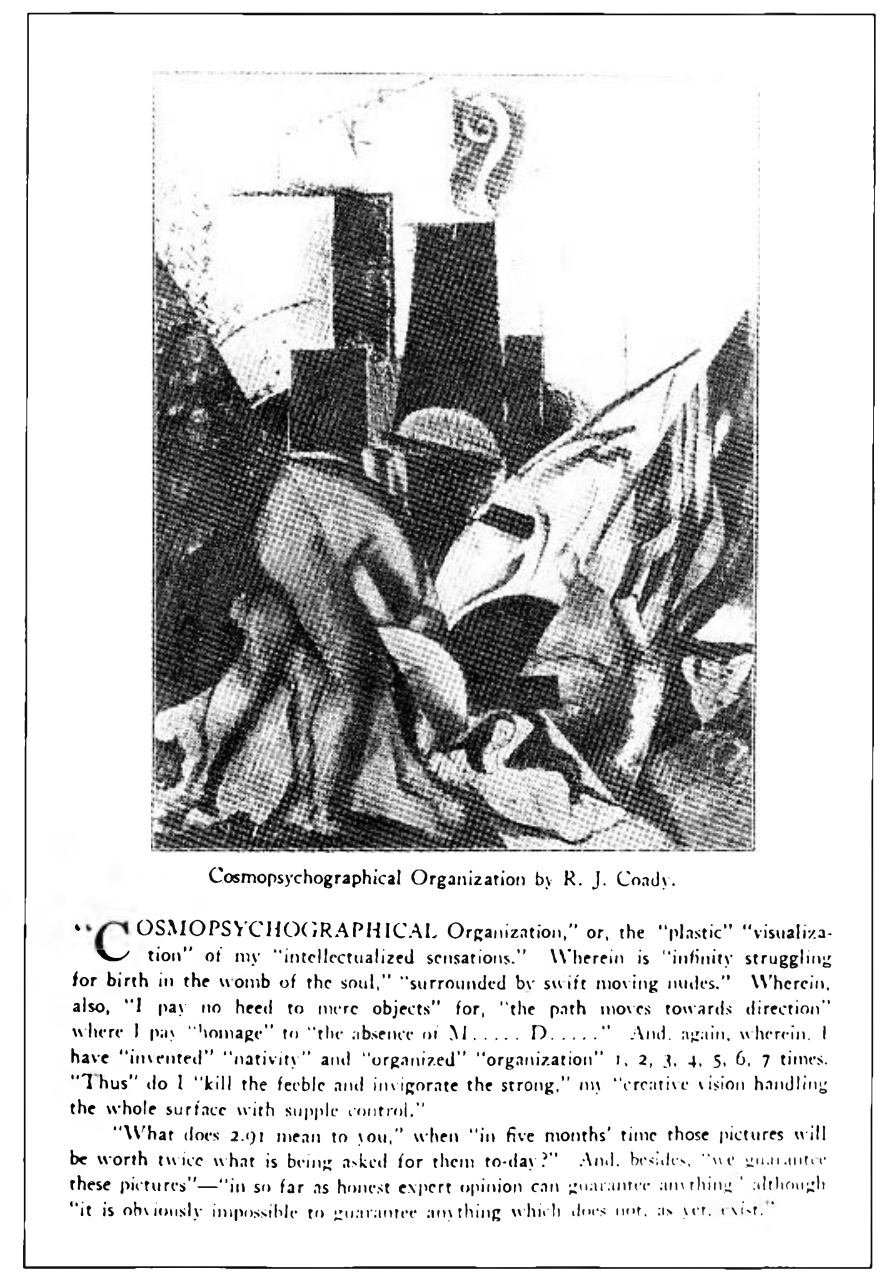

Figure 4. Robert J. Coady, Cosmopsychographical Organization, 1916. IIIustrated in The Soil I, I (December 1916).

answers did not quell the inquisitive nationalist. ${ }^{15}$ Unsatisfied with Wright's response, Coady submitted a rebuttal, which was printed in the March 19 edition of the newspaper:

\section{My question as to American art seems to have gone com- pletely ovcr the heads of these students, investigators and thinkers of American art. They are blind to the great things that are going on around them. They are blind to the big spirit here that has grown out of the soil and through the race and has already expresscd itself in terms of art that ranks with the great European epochs. ${ }^{16}$}

Six months later Coady continued to espouse his version of American modernism and to denounce the avant-garde in $\mathrm{Ncw}$ York in the first issue of The Soil. The inaugural issue featured Coady's Cosmopsychographical Organization (fig. 4), a collage of

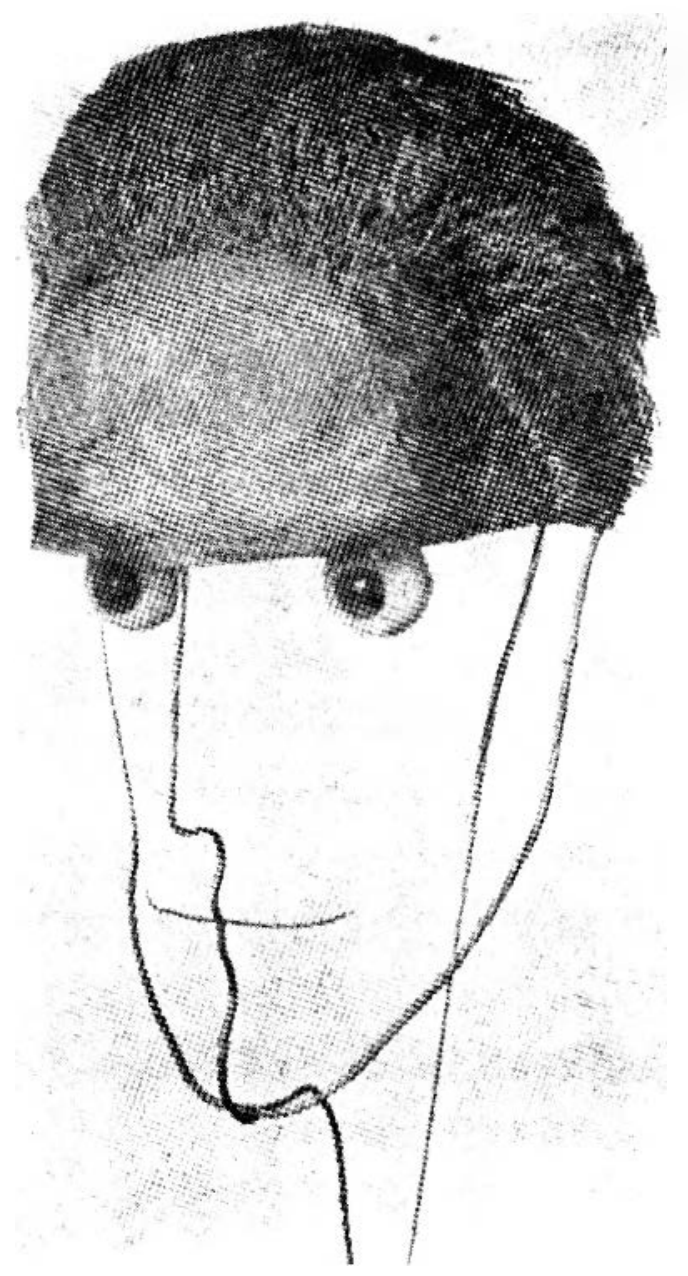

Figure 5. Jean Crotti, Portrall of Marcel Duchamp (Sculpture Mode to Meosure). 1915. (C) Estate of Jean Crotti / SODRAC (2008). Illustrated in The Soil I. I (December 1916).

reproductions of modern paintings, including work by Picasso and Matisse. In the caption Coady mocked artists' statements in the style of the Forum Exhibition catalogue and those from Alfred Stieglitz's gallery, 291.17 The same issue contained a letter from Coady addressed to Jean Crotti that criticized the French artist's I'ortrait of Marcel Duchamp (Sculpture Made to Measure) (fig. 5), a wire sculpture exhibited at the Montross Gallery during April 1916.18 The exhibition, labelled by the press as "The Four Musketeers," also included work by Marcel Duchamp, Albert Gleizes, and Jean Metzinger. ${ }^{19}$ Crotti's sculpture combined a cast of a forchead and hair (presumably Duchamp's), artificial eyes, and a wire structure forming the nose, mouth, and contour of the face. ${ }^{20}$ Crotti had discussed the portrait in World Magazine on 27 August 1916: "It is an absolute expression of my idea of Marcel Duchamp. Nor my idea of how he looks, so 




Figure 6. Marcel Duchamp. Fountoin. 1917. (C) Estate of Marcel Duchamp / SODRAC (2008) (Photograph by Alfred Slieglitz (c) Estate of Alfred Stieglitz / SODRAC [2008]). Illustrated in The Blind Mon 2 (May 1917).

much as my appreciation of the amiable character that he IS." 21

In his open letter Coady quoted Crotti's statement and satirized it extensively; he questioned the origin of "absolute expression" in the sculpture and the choice of materials. Crotti was unable to comment on Coady's criticism printed in The Soil's Deccmber 1916 issue because he had departed for Europe during the fall of 191622; however, Crotti's companions-Marcel Duchamp, Henri-Pierre Roché, louisc Norton, and Alfred Stieglitz-did respond in two issues of the The Blind Man and through the submission of Fountain (fig. 6) to the 1917 Independents Exhibition. ${ }^{23}$ This response went beyond a mere reply to Coady's criticism of Crotti; it extended to a scathing critique of Coady's nationalist vision for American art. The submission of a porcelain urinal as an artwork satirized his celebration of industrial objects as true American art forms. Similarly, articles in The Blind Man parodied his patriotic statements printed in The Soil.

\section{The Soil, The Blind Man, and the Fountain}

When Fountain was submitted to the Independents Exhibition, its authorship was a mystery. But Marcel Duchamp is generally recognized as the artist who selected and promoted the urinal as an art object. ${ }^{24}$ Fountain was a white porcelain urinal manufactured by J.L. Mott Iron Works, which had been signed with the pseudonym R. Mutt and dated 1917.25 Duchamp purchased the urinal with Joseph Stella and Walter Arensberg after the thought of the readymade occurred to him during a conversation with the two artisss. ${ }^{26}$ It was submitted to the Independents Exhibition relatively close to the show's opening dacc. The exhibition's organizers, the Society of Independenc Arcists, declared that the show was non-juried; every artwork submitted would be put on display. ${ }^{27}$ The only criteria for submitting a work was a five-dollar annual fec and a one-dollar initiation fee-both of which were included with Richard Mutr's Fountain. On 7 April 1917, a debate ensued between George Bellows and Walter Arensberg regarding Fountain's validity as an art object. ${ }^{28}$ 'Ihis led the Society's directors, not all of whom were present, to hold an impromptu mecting to decide the urinal's fate, and by a narrow vote Fountain was dismissed from the show. Duchamp, who was absent from the vote, resigned from the Society upon hearing of the decision. The Fountain's absence from the Independents Exhibition, however, did not reduce its visibility. It had the oppositc cffect: it fostered the urinal's notoriety. This was partly due to the press, which reported on Richard Mutt and his "bathroom fixture" after receiving notice of the Sociery's deviation from its democratic aims. ${ }^{29}$ The publication The Blind Man also disseminated information about Fountain. The May 1917 edition, which was cdired by Duchamp, Henri-Pierre Roché, and Beatrice Wood, printed a photograph of Fountain and two articles that defended the urinal as a legitimate art object. 30 These articlcs suggest that Duchamp chose the urinal as a response to Coady's pro-American rhetoric and his review of Crotti's wire sculpture.

In his scathing review of Portrait of Marcel Duchamp, Coady had directed the following questions toward Crotti:

\footnotetext{
Is your "absolute expression" the result of tastc?

Is your "absolute expression" the result of imagination?

Is your "absolutc cxpression" the absolute expression of a big artist, how docs it differ from the absolute expression of a little artist, how does it differ from the absolutc cxpression of a-plumber?

Does the difference make you a big artist, the litcle artist a little artist and the plumber a plumber?31
}

It is plausible that Fountain was a witty response to Coady's comparison of Crotri's "absolute expression of a big artist" to the "absolute expression of a-plumber." A passage in the article "Buddha of the Bathroom" by Louise Norton alludes to Coady's earlier concern with plumbing:

Like Mr. Mutt, many of us had quite an exhorbitant notion of the independence of the Independents. It was a sad sur- 
prise to learn of a Board of Censors sitting upon the ambiguous question, What is ART?

To those who say that Mr. Mutt's cxhibit may be Art, but is it the art of Mr. Murt since a plumber made it? I reply simply that the Fountain was not made by a plumber but the force of an imagination. 32

"The Richard Mutt Case," another article in the same issue of The Blind Man, appears to ridicule Coady's recommendations for a distinctive national art and his obsession with industrial products. The article, which was undoubtedly written with Duchamp's input, responded to critics' questions regarding the bathroom fixture's validity as an art object: "As for plumbing, that is absurd. The only works of art America has given are her plumbing and her bridges." 33 This statement resembles Coady's extensive list of authentic American art objects-except Duchamp took the liberty to add plumbing to his inventory. Arguably, he had selected the Fountain as a satirical addition to Coady's all-American art objects; it was another "beginning" not yet accepted by the art world. Instead of the grandiose and powerful Chambersburg Double Frame Steam Hammer, however, it was a "gross, offensive" and "indecent" 34 "article of bathroom furniture." 35

The correlation between Fountain and Coady's cry for an American art does not appear to be coincidental. In The Blind Man's previous issue, Henri Pierre Rochć illustrated the group's awareness of Coady and The Soil. Rochés introductory essay, which outlined the goals of the Independents and The Blind Man, stated, "Fvery American who wishes to be aware of America should read "Ihe Soil." 36 Roché was one of the few who knew of Duchamp's plans with the urinal, 37 and he likely wrote this statement as a subtle clue that reveals why Duchamp submitted Fountain to the exhibition. Incidentally, Duchamp and his circle distributed this issue on April 10, the day the Independents Exhibition opened to the public. ${ }^{38}$

A striking visual reference in The Blind Man accompanics the textual references that parody The Soil: the photograph by Alfred Stieglitz of Fountain appears to be a visual pun of Coady's Chambersburg Double Frame Stcam Hammer. The urinal's placement on its back and the photograph's careful lighting mimics the photograph of the industrial machine printed in Coady's first issue. The shadow within the urinal, along with the perforated drainage holes, creates an outline that imitates the negative space within the steam hammer, and the protruding wall mounts on the edges of the porcelain bathroom fixture mimic the base of the heavy industrial appliance. The readymade's title, Fountain, has an obvious connotation referring to the urinal's function of collecting and dispersing bodily fluids. In light of the readymade's resemblance to Coady's industrial hammer, the title possibly references the fountain at the base

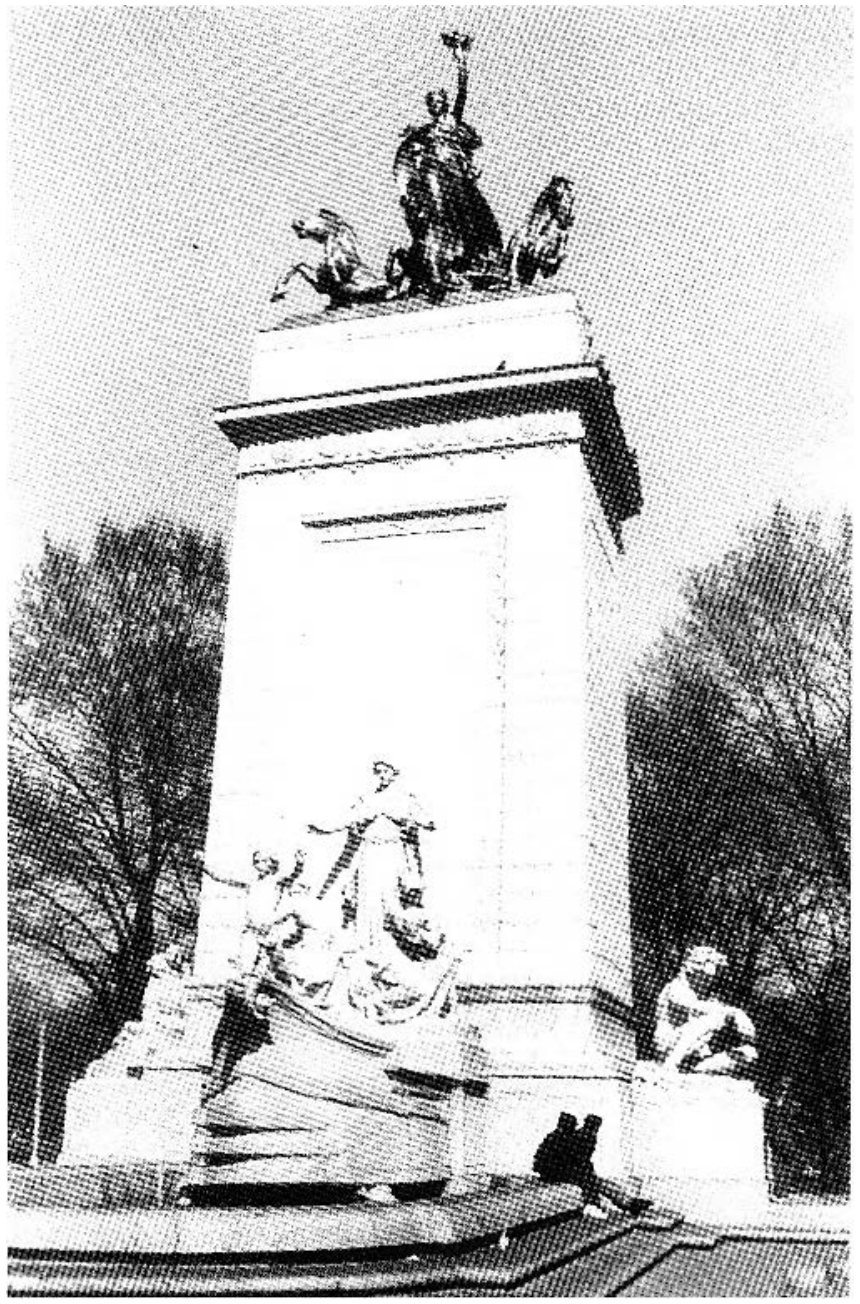

Figure 7. H. Van Buren Magonigle, architect, Attilio Piccirilli, sculptor, Maine Memorial, 1913. (Photo: Michele H. Bogart)

of the Maine Memorial (fig. 7). Duchamp, who is known for his aptitude for puns, may have conceived a title that combines the washroom reference with a subtle reference to the BeauxArts monument that Coady had compared with the Chambersburg Double Frame Steam Hammer. Duchamp's Fountain is similar in shape to the actual fountain that fronts the Maine Memorial. The raised side pedestals and the rounded fountain at the base of the Maine Memorial are visually similar to the wall mounts and the rounded basin of the urinal. Fountain's form draws attention to both objects in Coady's comparison of monuments. Viewed from above, Fountain's base mimics the fountain at the base of Maine Memorial. Viewed from the front, Fountain's shape mimics Coady's Chambersburg Double Frame Steam Hammer. 
Beatrice Wood recorded in her autobiography that Duchamp persuaded Stieglitz to photograph the urinal: "At Marcel's request, he agreed to photograph the Fountain for the frontispiece of the magazine. He was greatly amuscd, but also felt it was important to fight bigotry in America. He took great pains with the lighting, and did it with such skill that a shadow fell across the urinal suggesting a veil." 39 Although I am arguing that Wood was unawarc of the ulterior motives of the photograph, the urinal's carcful placement and lighting suggests there was a premeditated composition in mind. 40 On April 19, Srieglitz wrote to the art critic Henry McBride, "I wonder whether you could manage to drop in at 291 Friday sometime. I have, at the request of Roché, Covert, Miss Wood, Duchamp \& Co., photographed the rejected 'Fountain.' You may find the photograph of some use.-It will amuse you to see it.-The 'Fountain' is here too." 41 Stieglitz emphasized that the photograph was amusing, and the urinal itself was mentioned almost as an afterthought. McBride would have been amused with the carefully composed photograph because he was familiar with The Soil, and he would have seen the photograph of the Chambersburg Double lirame Stcam Hammer printed in the January 1917 issue. 42

Although Duchamp may have informed Stieglitz of how Fountain parodied Coady's call for an all-American art, he did not tell Stieglitz that he had sclected and submitted Fountain to the exhibition. (On April 19, Sticglitz wrote to Georgia O'Keefe, "[A] young woman (probably at Duchamp's instigation) sent a large porcelain urinal on a pedestal to the Independent." 1.3 Duchamp relayed a similar detail to his sister in France on April 11: "One of my female friends under a masculine pseudonym, Richard Mutr, sent in a porcclain urinal as a sculpture." 44 William Camfield suggests that Duchamp did not deceive Sticglitz and his sister Suranne because his account of a young woman submitting the urinal was not a falsification of the events but only a detail in Fountain's complex narrative. 45 He posits that Louise Norton may have acted as a "shipping agent" for Duchamp and that she had submitted Fountain on his behalf. It is apparent that Duchamp wanted to conccal his role in selecting and submitting the urinal-even after the Sociecy had rejected Fountain. Submitting the urinal under a pseudonym tested whether the directors would adhere to the Sociery's bylaw that no artwork would be refused. If Duchamp had submitted the urinal under his name-the name of a reputable and well-known avant-garde artist-instead of the unknown Richard Mutt then the directors might have accepted and exhibiced Fountain. His motive for distancing himself from Fountain's authorship after the Society of Independent Artists had rcjected the controversial artwork was tied to his resignation from the board of directors. Had it been known that Duchamp resigned because his own artwork was rejected then his resignation could have been perceived as an emotional reaction, a case of sour grapes. Instead, his resignation appeared to be a moral reaction based on his disagreement with Society's unethical decision to reject Richard Mutt's submission. A letter from Katherine Dreier to William Glackens, dated April 26, reveals that the Richard Mutt affair was still a contentious issue among the Society's board of directors and that it was unclear whether Duchamp and Mutt were the same artist. 46

Duchamp's submission of Fountain was not the only event at the Independents Exhibition that satirized Robert Coady's pro-American agenda. On the exhibition's opening night, Duchamp offered his opinion on which paintings were the kcy works in the show. 47 He knew that the critics valued his input; the success of his Nude Descending a Staircase shown at the Armory Show in 1913 had continued to kcep him in the spotlight. Duchamp, looking for every opportunity to disrupt the elitism in the art world, declared that Louis Eilshemius's Supplication and Dorothy Rice's Claire Twins were the two best paintings in the show. His choicc of Supplication, a painting of sub-standard quality, shocked the critics attending the exhibition. Eilshemius's reputation also stirred controversy; he was an eccentric, self-professed genius who often submitted letters to the art critics demanding that they recognizc his brilliance. Duchamp's gag fooled only a few critics, but it helped launch Eilshcmius's career nonetheless.

After discovering Eilshemius's supposed talent, Duchamp and his circle offered him an interview in The Blind Man of May 1917.48 The exposé on the well-known megalomaniac unleashed another pointed attack on Coady:

As Rousseau of the French spiric painced in France, does Eilshemius of the American Spirit paint in America....EiIshemius has not evolved, he has just grown to scatter seeds hap-hazard but at will to blossom in the amazing variations of his pictures, which, outside cvery academic or unacademic school, untouched by theory or "ism," survive as the unique arr form that has never been exploited by a dealer, never been in fashion! 49

This excerpt parodies Coady's introductory cssay, "American Art," printed in the first issue of the Soil:

...Steam Hammers, Stone Crushers, Steam Rollers, Grain Lilcvators, Trench Fxcavators, Blast Furnaces-This is American Art.

It is not a rcfined granulation nor a delicatc disease-it is not an ism. It is not an illustration to a theory, it is an expression of life-a complicared life-American life.

The isms have crowded it out of "the art world" and it has grown naturally, healthfully, beautifully. It has grown out of the soil and through the race and will continue to grow. It will grow and maturc and add a new unit to Art. ${ }^{50}$ 
By describing Eilshemius with the same rhetoric that Coady used in The Soil, Duchamp subtly mocked Coady by associating Coady's vision of American art with the artwork and reputation of a known sociopath.

Whether Coady noticed The Blind Man's satirical responses to The Soil remains unknown. In his last issue, which was printed in July 1917, he criticized the Independents Exhibition, but he did not mention the notorious Fountain. 51 He found fault with the exhibition; he considered the foreign pictures and sculptures to be better than those that were "a la foreign" and maintained that none of the works were true to American life. He disapproved of the organizers' choice to arrange the paintings alphabetically according to the artists' names. He also questioned their choice of a non-juried show and thought that personal judgments were essential for art to move forward:

It was through "mere personal judgments" that we came to know Greece, Rome and Egypt, Pompcii, Assyria and the Orient, Giotto, Michael Angelo [sic], Poussin, Lorrainc |sic| and Ingres, Cezanne [sic] and Rcnoir; and it will be through "mere personal judgments" that wc will know the steam shovel, the skyscraper, the movies and the electric light. The appreciation and enjoyment of art always was and always will be a matter of "mere personal judgments." 52

His essay on the exhibition preceded a commentary on some of the artists' paintings and sculptures that were on display. Coady, in his usual belligerent style, lampooned submissions by Brancusi, Demuth, Hartley, Marin, and Gleizes. One of the few artists who emerged unscathed was Coady's associate Michacl Brenner, whose submission "constitute|s] a quality of drawing which is not equalled in the exhibition." 53 (Other artists who received his praise were Picasso, Braque, and Gris. It is perhaps no coincidence that these three artists' works were sold at the Coady Gallery.

\section{Nationalism versus Individualism}

Duchamp's subtle parody of The Soil was not merely a vengeful attack in retaliation for Coady's criticism of Crotti; it likely stemmed from ideological differences as well. He remarked that he was influenced by Max Stirner's anarchist-individualist treatise Der Einzige und sein Eigentum. ${ }^{54}$ This contentious book prized individualism and called for the individual to rebel against the state, religion, and social institutions. Duchamp first encountered Stirner's text in the summer of 1912, and in the following year he applied Stirner's individualist-anarchist theories in his Three Standard Stoppages. Duchamp likely developed stronger anti-nationalist and individualist sentiments after witnessing the ravages of war in Europe. He would have observed how European countries strategically used patriotism, national- ism, and race to garner support for the First World War. ${ }^{55}$ On 19) January 1915, he wrote from Paris to Walter Pach: "Is life in New York still following the consequences of the war or is this crisis over? Surely it is. Thank you also for the catalogues. Here, there are naturally no exhibitions. Flags are the only things in color that one can see." 56 In the same letter he relayed to Pach, "I have been considered by the discharge board: and I have been condemned to remain a civilian for the entire duration of the war. They found me too sick to be a soldier. I am noc too sad about this decision: you know it well." 57

Nine months later in New York, Duchamp offercd his opinion on patriotism in an interview with the New York Tribune:

From a psychological standpoint I find the spectacle of war very impressive. The instincr which sends men marching out to cut down other men is an instinct worchy of careful scrutiny. What an absurd thing such a conception of patriotism is! Fundamentally all people are alike. Personally I must say I admire the attitude of combating invasion with folded arms. Could that but become the universal attitude, how simple the intercourse of nations would be. ${ }^{58}$

In the same interview he questioned whether place affected artists and their work: "So far as painting goes - it is a matter of indifference to me where I am. Art is purely subjective, and the artist should be able to work in one place quite as well as another." 59 This comment is contrary to Coady's call for an art that captures the American spirit arising from the soil. Duchamp's anarchist-individualism would have been at odds with Coady's passionate American nationalism. Louise Norton's remark regarding Richard Mutt, "Is he serious or is he joking?' Pcrhaps he is both!"60 reflects Duchamp's bitter irony. He was simultaneously teasing Coady and delivering a strong subversive message that challenged the avid patriotism advocated in The Soil.

Duchamp likely recognized that Coady's call for an American art tied to the nation's spirit and soil rcscmbles Maurice Barrès's nationalistic motto and concept "la terre et les morts" ("the earth and the dead"). ${ }^{61}$ Barrès advocated a French integral nationalism that was based on the citizens' ancestry and spiritual connection to French soil.62 This form of nationalism was adopted by right-wing politicians and groups, such as the Action Française, and was used to foster anti-German and anti-Semitic sentiments in the French populace prior to and during the First World War. ${ }^{63}$ Duchamp would have obscrved how Barrès's nationalism based on blood and soil inspired France to take up arms against Germany. With his knowledge of the dangers associated with organic nationalisms, he would have been especially critical of Coady's vision of American art: "It has grown out of the soil and through the race and will continue to grow." 64

Another catalyst that may have prompted Duchamp to deride The Soil was Coady's privileging of taste within the arts. Al- 
though Coady disapproved of all the Euro-derived "isms" in the modern art world, he was not opposed to older European traditions influencing his conception of an indigenous American art.

The Old World can teach us a lot. Her masters can develop our taste and help us realize ourselves. Greece can show us where subrle emphasis goes farther than exaggerated distortion and where affinity of subject and object will generatc a work of art. Rome can teach us proportion and the division of space. Lorrain and Von Gogh [sic] can show us that color is light. Cezanne [sic] can show us form.

Taste would alter the Steam Hammcr. It would change a handle here or a bolt there, it would straighten this line or curve that, it would vary textures and show a delight in the meeting of planes-and if it equalled the creative construction of the hammer we'd have a mighty art! ${ }^{65}$

Duchamp, on the other hand, strongly opposed the valuing of aesthetics and taste.66 In 1963, he remarked in an interview with Francis Roberts, "Taste is the enemy of art, A-R-T." 67 He had sought to undermine taste by creating his readymades and advocating them as art objects. ${ }^{68}$ In an interview with Hans Richter, he confirmed, "When I discovcred ready-mades I thought to discourage aesthetics." 69 In his "Apropos of 'Readymades," he also noted that his choice of readymades "was based on a reaction of visual indifference with at the same time a total absence of good or bad taste...in fact a complete anesthesia."70 Duchamp chose the urinal because it was an absolute all-out attack on taste. In an interview with Otto Hahn, he revealcd, "[Fountain] sprang from the idea of making an experiment concerned with taste: choose the object which has least chance of being liked. A urinal - very few people think there is anything wonderful about a urinal. The danger to be avoided lies in aesthetic delectation." 71 William Camfield argues that aesthetics dictated Duchamp's choice of the urinal and that Duchamp's later accounts are a falsification of what occurred in 1917.72 Camfield's conclusion, however, is incorrect because it disagrees with Mina Loy's remarks in a poem published in the May 1917 edition of The Blind Man: "Anyhow, Duchamp mediating the levelling of all values, witnesses the elimination of Sophistication."73 This statement alludes to Duchamp's crusade to abolish taste--a value that is undoubtedly associated with sophistication.

Duchamp's motives for challenging aestherics and taste, two socially detcrmined conventions, derived from his reading of Stirner's anarchist-individualist philosophy, which called for the abolishment of all social norms and hierarchies. ${ }^{74}$ Fountain also questioned the role of the "artist"-it was an attempt to disrupt the social norms and values that defined an individual as an artist. ${ }^{75}$ His submission of the urinal as an art object tried to kick out the pedestal from under the "artist" and destabilize the elcvated status the artist enjoyed in the social hierarchy.

\section{Robert Coady and Alfred Stieglitz}

Alfred Kreymborg described Coady as a "pugnacious, red-headed Irishman...[who] had incisive ideas about modern art."76, At one point, Coady asked Kreymborg to be the literary editor for The Soil and proposed that The Soil should collaborate with Kreymborg's existing publication Others. 77 Kreymborg decided against the proposal, and the merger never materialized. Robert Alden Sanborn wrote about Coady's aggressive attitude in a commemoration of the quarrelsome art dealer:

As an art critic Bob Coady was a rare cxample of the successful fighter, the boxer-slugger. He loved to give punishment and he was ready to take it if thercby he could land the damaging punch. He fought for the love of fighting, and he hit for love of hitting. And he sometimes hit the wrong person, and at other times he hit too hard. He was a good harcr becausc he was a great lover of the truth. He was what is known by the timid, the incurious, and the smugr, as an extremist. 78

Coady's "pugnacious" and "extremist" demeanour suggests that his criticisms in the Soil were not in mere jest but belligerent attacks on his opponents. Alfred Stieglitz was one of his recurring adversarics. While sitting on the sclection panel for the Forum Exhibition in 1916, he was subjected to Coady's condemnation of the exhibition's aims. Coady also attacked Stieglit\% in the caption below the collage Cosmopsychographical Organization: "What does 2.91 mean to you,' when 'in fivc months' time those picturcs will be worth twice what is being asked for them to-day?'"79 This was a pointed attack on the anti-commercial focus of Stieglitz's gallery.8) Stieglitz was an anarchist and 291 was an exhibition space that was guided by his idcals. ${ }^{81}$ It was a gallcry where artists could exhibit their work without any costs incurred and sell their work without any commission levied. Coady's attack on Stieglitz undoubredly hit a nerve, especially because of a business contract settled approximatcly two and half years earlier. Daniel-Henry Kahnweiler, the Cicrman art dealer who had exclusive rights for handling the sales of Picasso's and Braque's artworks, selected Coady and Brenner's Washington Square Gallcry over Stieglitz's 291 as the sole representative for his salcs in Ncw York. ${ }^{82}$ Upon receiving this news from Marius de Zayas, Sticglitz replied,

As for Kahnweiler I am not at all surprised at what you wrote me. As a matrer of fact I expected nothing else. I had heard that Brenner and Cody [sic], an old friend of Max Weber's (they have had a falling out lately), had opened a little gallery on Washington Square. Brenner was to be in Paris and send things over. Cody [sic] was to stay in New York. I was informed that Kahnweiler had given Brcnner a sole 
agency. But I hardly could believe that Kahnwciler would be so devilish[ly] stupid. If he only knew how slick and irresponsible, how absolutely without conscience the average American is, Kahnwcilcr might spare himself some great disappointments. For these disappointments are in store for him, I am sure, as far as this special little gallery gocs. But perhaps I am mistaken. Well, as far as we are concerned it makes no difference. Washington Square is to be purely commercial, and as long as Kahnweiler has become purely so, the less we have to do with him the better. ${ }^{83}$

Coady also attacked Sticglitz indirectly by deriding the artists exhibited at 291 and the Modern Gallery. He mocked Marsden Hartley by publishing a photo of his painting Motion adjacent to A Busted Ford, a painting by thirteen-year-old P.W. Henderson, with the caption: "Which has-the motion?"81 Coady disparaged Stieglitz's circle in his review of the Independents Exhibition, reserving his harshest criticisms for Brancusi, Demuth, Hartlcy, and Marin. ${ }^{85}$

Stieglitz remarked on The Soil in an ambiguous response to Mabel Dodge: "Yes, The Soil is a queer one.... I enjoyed it probably more than Coady himself." 86 Although this remark has been construed as praise for Coady, 87 it suffuses sarcasm. He labelled The Soil "queer," and his enjoyment of the publication likely derived from the laughter evoked by Coady's manifestonot because he agreed with the passionate nationalism espoused in the magazine.

Stieglitz and Duchamp did not share an amicable rclationship at the outset. In a recollection of Stieglitz, Duchamp noted, "He didn't amuse me much, and at the beginning I must say he didn't think much of me either; I struck him as a charlatan. He was very bound up with Picabia, whom he had met in 1913; then later he changed his mind about mc, and we became good fricnds. These are things that one cannot explain."88 Coady's incessant attacks on Sticglitz and his circle may have influenced the photographer's decision to collaborate with Duchamp on Fountain. Not only did he help Duchamp by photographing the urinal, he also put the bathroom fixture on display at his gallery 291.89 Duchamp probably knew that Stieglit\% disliked Coady and this may have influenced his choice to approach Sticglitz to photograph Fountain. If Duchamp had merely wanted a photograph of the urinal then Man Ray, a photographer with considerable experience, could have taken it. ${ }^{90}$

\section{Robert J. Coady and New York Dada}

Dada found its way into Ncw York during the fall of 1916 when Tristan Tzara wrote to de Zayas about the movement's activities in Zurich. ${ }^{1}$ Along with the letter were ten copies of the Dadaist publication Cabaret Voltaire. The details regarding Dada's de- velopment in New York are somewhat obscure, and it has been difficult to establish which artists were involved. Duchamp's iconoclastic and anti-art antics with the submission of Fountain to the Independents Exhibition and the related articles in The Blind Man are significant New York Dada events. The height of the movement was during April 1921, when the Socićc Anonymc held a group cxhibition that included Marsden Hartley's lecıure "What is Dadaism?" I Juring the same month Marcel Duchamp and Man Ray edited and printed the first and only issuc of New York Dada." 2

In a number of recent analyses, art historians have argucd for Coady's inclusion within the New York Dada group. ${ }^{93}$ However Coady's viewpoints contrast with key characteristics of I)ada: rebelling against capitalism, patriotism, and the cstablished art institutions and traditions. ${ }^{94}$ Hugo Ball wrote that the aim of his Dadaist group in Zurich was "to remind the world that there are independent men- bcyond war and nationalism-who live for other ideals." 95 This is a different aim from Coady's intentions in The Soil, a magazinc that aggressivcly promoted a nationalist art form. Coady's commcrcial interest in art, which is evident in his criticism of the Forum Exhibition and in Stieglitz's surviving comments on Coady's art dealings, conflicts with the anti-capitalist charactcristics of Dada. Coady's photoessay of steam-hammers and cranes, "Moving Sculpture Series," venerated America's industry. Hc belicved that the machines were art objects that embodied the Amcrican spirit-what the industrial machinery conveyed was essentially the spirit of capitalism. C'oady's program for American art also mitigated against Dada's attack on hierarchical values. He believed that taste was necessary to discern what constituted art and that it could refinc American art objects: "Taste would alter the Steam Hammer." 96 Coady's actions cannot be considered iconoclastic or anti-art, since he did not demand a complete rejection of past traditions. He proposed that artists could learn from canonical works ranging from Greek and Roman models to the Post-Impressionist paintings of Vincent Van Gogh and Paul Cízanne. ${ }^{97}$

In The Cireat American Thing: Modern Art and Identity 1915-35, Wanda Corn suggests that Marcel Duchamp and Robert Coady both had similar goals and ideals. ${ }^{98}$ She constructs a narrative around the two, supposing that they were "kindred spirit[s]." 99 She bases this assumption on a letter Duchamp sent to Crotti and his sister Suzannc, dated 20 ()ctober 1920. He reported that Montross and De Zayas werc out of town and that "[o]ur friend Coady has disappeared from circulation." 100 Corn takes this singular quote literally, maintaining that Duchamp, Crotti, and Coady were actually good friends. ${ }^{101}$ Duchamp's words must be considered with caution because he is renowned for his wit and satire. It also seems doubtful that Coady and Crotti were friends in light of Coady's scathing review of the Portrait of Marcel Duchamp. Corn also takes a literal reading of 
Duchamp's statement that declared plumbing and bridges were America's only art forms. 102 She suggests that Duchamp was in awe of America's plumbing because the Furopean toilets, bathtubs, and water pipes paled in comparison. ${ }^{103}$ Corn contends that Duchamp's admiration of America's consumer culture, technology, and manufactured goods prompted him to choose the snow shovel and urinal as readymades. ${ }^{104}$ Corn's conclusions that Duchamp and Coady shared a similar nationalistic perspective and that Duchamp based his choice of the readymades on his admiration of American consumer culturc are, however, questionable. Duchamp expressed anti-nationalist and individualist sentiments that contrast with Coady's passionate nationalism. He chose his readymades because they challenged the accepted notions of aesthetics and taste, and sclected massproduced goods because they were objects that lacked creative input - not because he was enamoured with the products of America's burgeoning industrial cnterprises.

\section{Conclusion}

Coady must be acknowledged as a strong, outspoken critic of modern art in America; however, Coady was not part of New York Dada. Fountain's resemblance to the Chambersburg Double Frame Steam Hammer and the references in The Blind Man that parody Coady's statements are strong indications that Coady and his project for an American art werc the subject of a Duchampian gag. Coady must be noted in conjunction with New York Dada, since his writing in The Soil was a reaction to the movement and presumably became the foundation for a Dadaist parody. The Soil was a tribute to America; it is a form of Americana, but it is a far cry from being Dada.

\section{Acknowledgement}

The author wishes to thank Allan Antliff for his insights, advice, and suggestions. This essay is based on work complcted for a graduate seminar on New York Dada, which Allan Antliff taught at the University of Victoria during the spring of 2004 .

\section{Notes}

1 Judith Lilczer, "Robert J. Coady, Forgotten Spokesman for AvantGarde Culture in Amcrica," American Art Review II, 6 (November-December 1975): 77-89; Judith Zilczer, "Robert J. Coady, Man of The Soil," New York Dada, ed. Rudolf E. Kuenzli (New York, 1986), 31-43; Ruth I.. Bohan, "Whitman's 'Barbaric Yawp' and the Culture of New York Dada," Dada New York: New World for Old, Crisis and the Arts: the History of Dada VIII, ed. Stephen C. Foster (New York, 2003), 35-57; and Dickran Tashjian,
Skyscraper Primitives: Dada and the American Avant-Ciarde, 19101925 (Middletown, Conn., 1975), 71-84.

2 Coady's promorion of European modern art and his sales of reproductions to students may appear to contradict his disapproval of European art's influence on American art. Coady's criticism was not directed at all Furopcan artists and artworks, but towards American artists who imitated European art. Coady believed that Luropean modernism was authentic since it emerged in Europe and from European traditions. He exhibited and sold European modern artworks so that the public and other artists could see the artworks for their quality and not for the sake of being models to be copied in America. See Zilczer, "Robert J. Coady, Man of The Soil," 37-39.

3 Robert J. Coady, "American Art," The Soil I, 2 (January 1917): 54.

4 Coady, "American Art," The Soil 1, I (Dccember 1916): 4.

5 Coady, "Moving Sculpture Series," The Soil I, 2: following 56.

6 The Soil I, 2: following 72. For a discussion of H. Van Buren Magonigle and Atrilio Piccirilli's Maine Memorial, see Michcle H. Bogart, Public Sculpture and the Civic Ideal in New York City, 189()-1930)(Chicago, 1989), 185-204.

Coady, "American Art," The Soil I, 2: 55.

8 The Soil I, 1: following 24.

9 Coady, "The Stampede," The Soil 1, 1: 24.

10 Robert Alden Sanborn, "Ihe Fight," The Soil 1, 2 (January 1917): 67-68; Sanborn, "Notes of the Fight," The Soil, I, 2: 68-71; Coady, "Ted Lewis," The Soil I, 2: 71-72; Sanborn, "Fight Nights at the Armory A. A.," The Soil I, 3 (February 1917): 130-34; "Arthur Cravan vs. Jack Johnson," The Soil I, 4 (April 1917): 161-62; and Sanborn, "Fight Nights," The Soil I, 5 (July 1917): 214-18.

11 Bohan, "Whitman's 'Barbaric Yawp,"” 38-39, 53.

12 John Quinn, cited in Bohan, "Whitman's 'Barbaric Yawp," 39.

13 "Current News of Art and the Exhibirions," New York Sun, 12 March 1916, 8. Also see Dennis Raverty, "A Split among the Modcrns: Avant-Garde Paradigms at the Time of the Forum Exhibition of 1916," Rutgers Art Review XV (1995): 59-63.

14 "In Explanation," The Forum Fxhibition of Modern American P'ainters, exh. car., New York, Anderson Galleries (New York, 1916), 5-6.

15 Wrighr's response included: "Mr. Coady says he is an art buyer. 1) oes he then consider the market value of his purchases five years hence? If so, he lacks the true art lover's instinct. It is not the desire of the committce or any other respecter of art to encourage art gambling. What we do want is to create an appreciation of art-to make these pictures personally worth what is asked for them." "Current News of Art and the Exhibitions," New York Sun, 12 March 1916, 8.

16 "Current News of Art and the Exhibitions," 8.

17 Coady, "Cosmopsychographical Organization," The Soil I, 1: following 30. The quotations "kill the feeblc and invigorate the strong" and "creative vision handling the wholc surface with supple 
control" were excerpted from Morgan Russell's artist statement in the Forum Exhibition catalogue; on the page opposite to Morgan Russell's artist statement was a reproduction of Russell's Cosmic Synchromy. See Morgan Russell, "Explanatory Nore," The Forum Exhibition of Modern American Painters, n.p.; and Zilczer, "Robert J. Coady, Man of'Ihe Soil," 39. The title may be a barb directed at Cosmism, a movement promoted by John Weichsel. For a discussion of Cosmism, see Allan Antliff, "Cosmism or Amorphism," Anarchist Modernism: Art, Politics, and the First American AvantGarde (Chicago, 2001), 53-72; and Allan Antliff, "Cosmic Modernism: Elie Nadelman, Adolf Wolff, and the Materialist Aesthetics of John Weichsel," Archives of American Art Journal XXXVIII, 3 \& 4 (1998): 20-29.

Coady printed a similar parody in the Iecember 1916 issue. He juxtaposed Stanton Macdonald-Wright's Synchromist painting Organization, 5 and an excerpt from his artist statement with a photograph of an arrangement of hats found in a shop window and a statement by Gilbert McGowan, the window dresser. See The Soil I, 1: following 18; and Stanton Macdonald-Wright, "Explanatory Note," The Forum Exhibition of Modern American Painters, n.p.

18 Coady, "Letter to Jean Crotti," The Soil 1, 1: 32-34; and Exhibition of Pictures by Jean Crotti, Marcel Duchamp. Albert Gleizes, Jean Metzinger, exh. cat., New York, Montross Gallery (New York, 1916), Miscellaneous art exhibition catalogue collection, 18871934, Archives of American Art, Smithsonian Institution.

19) Francis M. Naumann and Beth Venn, eds., Making Mischief: Dada invades New York (New York, 1996), 63.

20 Francis M. Naumann, New York Dada: 1915-23 (New York, 1994), 103. A photograph of Crotti's Portrait of Marcel Duchamp (Sculpture Made to Measure) is in the Jean Crotti papers, Archives of American Art, Smithsonian Institution

21 Jean Crotti, citcd in Coady, "Letter to Jean Crotti," The Soil I, 1: 32 .

22 Duchamp reported in a letter to his sister that Crotti had left New York. Marcel Duchamp to Suzanne Duchamp, 17 October 1916, Jean Crotti papers, Archives of American Art, Smithsonian Institution. Crotri's Portrait of Marcel Duchamp (Sculpture Made to Measure) was displaycd at the first annual exhibition of the Society of Independent Artists in 1917. See Francis M. Naumann, "The Big Show: the First Exhibition of the Society of Independent Artists; Part I," Artforum XVII, 6 (February 1979): 38.

23 The two issues of The Blind Man were published by Marcel Duchamp, Henri-Pierre Roché, and Beatrice Wood in New York in April and May 1917.

24 For an overview of the events pertaining to Fountain, see William A. Camfield, "Marcel Duchamp's Fountain: Its History and Aesthetics in the Context of 1917," Marcel Duchamp: Artist of the Century, eds. Rudolf E. Kuenzli and Francis M. Naumann (Cambridgc, 1989), 64-94.
25 Duchamp revealed in an intcrview with Otto Hahn, "Mutt comes from Mott Works, the name of a large sanitary equipment manufacturer. But Mott was too close so I altered it to Mutt, after the daily strip cartoon 'Mutt and Jeff which appeared at the time, and with which everyone was familiar. Thus, from the start there was an interplay of Mutt: a fat little funny man, and Jeff: a tall, thin man....I wanted any old name. And I added Richard [French slang for money-bags]. That's nor a bad name for a pissotiére." Marcel I Juchamp in Otto Hahn, "Passport No. G255300," Art and Artists I, 4 (July 1966): 10.

26 Arturo Schwarz, The Complete Works of Marcel Duchamp, 2nd cd. (New York, 1970), 466.

27 An undated announcement titled The Society of Independent Artists, Inc. outlined the Socicty's principles and the guidelines for submitting artwork for the April 1917 exhibition. A copy of this announcement is in the Miscellaneous art exhibition catalogue collcction, 1887-1934, Archives of American Art, Smithsonian Institution. William Camfield notes that this announcement was circulared in January 1917. Camfield, "Marcel Duchamp's Fountain," 66.

28 Camfield, "Marcel Duchamp's Fountain," 69-70; and Bcatrice Wood to Louise Arensberg, 10 August 1949, Bcatrice Wood papers, Archives of American Art, Smithsonian Institution.

29 Camfield, "Marcel Duchamp's Fountain," 67-68.

30 P'Bl, the initials of [Henri-] P[ierre Roché], B[eatrice Wood], and T[otor], appcars on the cover of The Blind Man 2 (May 1917). A copy of the May 1917 issue of The Blind Man is in the Beatrice Wood papers, Archives of American Art, Smithsonian Institution. lotor, which derived from Victor, was I)uchamp's nicknamc. See Bcatrice Wood to Louise Arensberg, 10 August 1949, Bcatrice Wood papers, Archives of American Art, Smithsonian Institution. The photograph of Fountain was printed in The Blind Man 2 (May 1917): 4 .

31 Coady, "Letter to Jean Crotti," The Soil I, 1: 32.

32 I ouise Norton, "Buddha of the Bathroom," The Blind Man 2: 6.

33 "The Richard Mutt Case," The Blind Man 2: 5.

34 These three adjectives are from Beatricc Wood's account of Gcorge Bellows's words. Bellows was on the Board of Directors of the Independents and was outraged with the submission of Fountain. Bcatrice Wood, I Shock Myself: The Autobiography of Beatrice Wood, ed. Lindsay Smith (San Francisco, 1988), 29.

35 Unsigned review, "His Art 'loo Crude for Independents," The New York Herald, 14 April 1917; cited in Camfield, "Marcel Duchamp's Fountain," 6-68.

36 Henri Pierre Roché, "The Blind Man," The Blind Man 1 (April 1917): 6.

37 Camfield, "Marcel Duchamp's Fountain," 79.

38 Camfield, "Marcel Duchamp's Fountain," 67.

39 Wood, I Shock Myself, 30. Camfield discusses Wood's account of Fountain in Camfield, "Marcel Duchamp's Fountain," 74. Wood 
recalled in a memoir of Duchamp, "He took me with him to Stieglitz's gallery, and, after a long conversation and a good deal of laughter, both men agreed that Stieglitz should make a photograph of Fountain. But the image should be seen by many. Pcrhaps, they thought, it would be a good idca if the photograph were reproduced on the cover of an art magazine." Beatrice Wood, "Marccl," Marcel Duchamp: Artist of the Century, eds. Rudolf E. Kuenzli and Francis M. Naumann (Cambridgc, Mass., 1989), 14.

Stieglitz wrote, "The 'Blind Man' wants to use the matter [the phorograph of Fountain] for a number-a discussion of 'Art," in Alfred Stieglitz to Georgia O'Keeffe, 19 April 1917, Alfred Stieglitz / Georgia O'Kccffe Archives, Yale Collection of Amcrican Literature, Beinecke Rare Book and Manuscript Library. Duchamp probably approached Stieglitz about phorographing Fountain on April 13. Beatrice Wood recorded in her diary an entry for 13 April 1917: "Sce Stieglitz about 'Fountian [sic].'” Beatrice Wood papers, Archives of American Art, Smithsonian Institution.

40 Wood's account of a veil refers to how Fountain's shape suggests the shape of a Madonna or a Buddha. I agrec with Francis Naumann's suggestion, "I think he just lec things take thcir own natural coursc. I can sce him arranging to have the urinal brought to Stieglitz, but when someone associated its shape with that of a Madonna or a Buddha, I think he would have just gone along with the idea." Francis Naumann, "I)iscussion," in Thierry de Duvc, "Given the Richard Mutt Casc," Ihe Definitively Unfinished Marcel Duchamp, ed. Thicrry de Duve (Cambridgc, Mass., 1991), 236.

41 Citcd in Camfield, "Marcel Duchamp's Fountain," 74-75.

12 Henry McBride wrote a favourable review of the I)ccmber 1916 issue of The Soil, which he concluded with, "I shall await the January issue with impacience." Scc Henry McBride, "The Soil, A Magazinc of American Art," New York Sun, 17 December 1916, 12; and Zilczer, "Robert J. Coady, Forgotten Spokesman," 86.

13 Alfred Stieglitz to Cicorgia O'Keeffe, 19 April 1917. Alfred Stieglitz / Cieorgia O'Kccffe Archives, Yale Collcction of American Literature, Beineckc Rare Book and Manuscript Library.

1 "Une de mes amics sous un pseudonyme masculin, Richard Mutt, avait envoyé une pissotière en porcelaine comme sculpture." Marcel Duchamp to Suzanne Duchamp, 11 April 1917, Jcan Crorti papers, Archives of American Arr, Smithsonian Institution; English translation from Francis M. Naumann, "Affectucusement, Marccl: 'len Letters from Marcel Duchamp," Archives of American Art Journal XXII, 4 (1982): 8.

45 Camficld, "Marcel Duchamp's Fountain," 72.

46 See Camfield's discussion of 1)reier's letter in Camficld, "Marcel Duchamp's Fountain," 73-74.

47 Naumann, "The Big Show," 37. In an interview conducted by Paul Karlstrom, Beatrice Wood described Duchamp's discovery of Louis M. Eilshemius at the Independents Exhibition in 1917. Beatrice Wood, in Paul Karlstrom, "Oral history interview with Beatricc Wood, 1976 Aug. 26," Archives of American Arr, Smithsonian
Institution, http://www.aaa.si.edu/collections/oralhistories/ transcripts/wood76.htm (accessed 18 September 2006).

48 Although Mina Loy submitted the article to The Blind Man, there is enough evidence to suggest that Duchamp had helped Loy with writing the interview. Scc de Duve, "Given the Richard Mutt Case," 201-02.

49 "Pas de Commentaires! Louis M. Eilshemius," The Blind Man 2: 11.

50 Coady, "American Art," 'The Soil I, 1: 4.

51 Coady, "The Indeps," The Soil I, 5: 202-05. Coady may have stopped publishing The Soil because of economic difficultics he was experiencing with his gallery. In mid-May 1917, Coady wrote to Michael Bronner, his business partner in Paris, about the gallery's financial problems. On 26 June 1917, Brenner wrote to his brother Sam about the warning and his disappointment with Coady: "To me Coady's lcters usually hinted not so much of difficulties as of much hard work to do and always ended up with a spark of hope and encouragement which lulled me to slcep untill [sic] latcly when I couldn't accept with an easy mind the fact that Coady couldn't scnd me even so littlc as 50 dollars after all my appeals and notwithstanding the fact that the gallery owes me more than that. Then, in his last letter to me dating back about 6 weeks Coady comes our for the first time with the statement that unless the gallery gets some action soon, we'll be in an awfull |sic| hole. do you get it? 'an awfull [sic| hole.'” Michael Brenncr to Sam Brenncr, 26 June 1917, Michael Brenner papers, Archives of American Art, Smithsonian Institution.

52 Coady, "The Indcps," 204.

53 Coady, "Notes on the Exhibition," The Soil I, 5: 205-10.

54 Der Einzige und sein Eigentum was published in 1845. In 1900 it was published in French as L'unique et sa proprićté. On Stirner's individualist-anarchism and its influence on Duchamp's Three Standard Stoppages, see Francis M. Naumann, "Marcel Duchamp: A Reconciliation of Opposites," The Definitively Unfinished Marcel I) uchamp, cd. 'Thierry de 1)uve (Cambridge, Mass., 1991), 53-55; Antliff, Anarchist Modernism, 76-77, 90; and Allan Antliff, "Anarchy, Politics, and Dada," Making Mischief: Dada invades New York, eds. Francis M. Naumann and Beth Venn (New York, 1996), 212.

55 Mark Antliff and Patricia I.eighten, Cubism and Culture (New York, 2001), 111-35, 197-214.

56 "La vie à New York a-t-clle encore un contre coup de la gucre ou bien cette crise est-cllc passée? Sans doutc. Merci aussi des catalogues. Ici pas d'exposition naturellement. Des drapeaux, c'cst tout ce qu'on peut voir de couleur." Marcel Duchamp to Walter Pach, 19 January 1915, Walter Pach papers, Archives of American Art, Smithsonian Institution; English translation from Francis M. Naumann, "Amicalement, Marcel: Fourteen Letrcrs from Marcel Duchamp to Walter Pach," Archives of American Art Journal XXIX, $3 \& 4$ (1989): 38.

57 "J'ai passé le conseil de réforme: et je suis condamné à rester civil 
pendant toutc la durée de la guerre. Ils m'ont trouvé trop malade pour être soldat. Je ne suis pas fâché de cette décision: vous le savez bien." Marcel Duchamp to Walter Pach, 19 January 1915, Walter Pach papers, Archives of American Arr, Smithsonian Institution; English translation from Naumann, "Amicalcment, Marcel: Fourteen Letters from Marcel Duchamp to Walter Pach," 37.

58 "French Artists Spur on an American Art," New York Tribune, 24 October 1915, reprinted in Rudolf E. Kuenzli, cd., New York Dada (New York, 1986), 133-34.

59 "French Artists Spur on an American Art," reprinted in Kuenzli, ed., New York Dada, 133.

60 Norton, "Buddha of the Bathroom," 6.

61 For a detailed examination of Barrès's politics and literary works, see Robert Soucy, Fascism in France: The Case of Maurice Barrès (Berkeley, 1972), 1-25, 69-115. See Mark Antliff's discussion of Barrès in Mark Antliff, Avant-Garde Fascism: The Mobilization of Myth, Art, and Culture in France, 1909-1939 (Durham, 2007), 84-85.

62 Barrès introduced some of these ideas in Les Déracinés, which was published in 1897. Les Déracinés was Barrès's most popular literary work and appcalcd to the French right during the early twentieth century. See Soucy, Fascism in France, 3-4.

63 Soucy, Fascism in France, 10-13, 23. Barrès espoused his views on integral nationalism in numerous propagandist works during the First World War. One cxample is "Les Traits Éternels de la France," a lecture Barrès dclivercd in London on 12 July 1916; see Maurice Barrès, Les Iraits Eternels de la France, with notes by Fernand Baldensperger, (New Haven, 1918).

64 Coady, "American Art," The Soil I, 1: 4.

65 Coady, "Amcrican Art," The Soil I, 2: 54-55.

66 As Allan Antliff has demonstrated in "Anarchy, Politics, and Dada," $213 n 25$.

67 Marcel Duchamp in Francis Roberts, "I Propose to Strain the Laws of Physics," Art News I.XVII, 8 (December 1968): 62. Two other interviews in which Duchamp discussed taste are in Jamcs Johnson Sweency, "A Conversation with Marcel Duchamp," television interview, NBC, January 1956, Salt Seller: The Writings of Marcel Duchamp (Marchand du Sel), eds. Michel Sanouillet and Elmer Peterson (New York, 1973), 133-34; and Hahn, "Passport No. G255300," 10 .

68 In the interview with Roberts, Duchamp defined the readymade as "a work of art without an artist to make it." Roberts, "I Propose to Strain the Laws of Physics," 47. Duchamp discusscd some of his early readymades in a letter to Suzanne Duchamp, 15 January 1916, Jean Crotti papers, Archives of American Art, Smithsonian Institution.

69 Marcel Duchamp, cited in Camfield, "Marcel I) tain," 80.

70 Marcel Duchamp, "Apropos of Readymades," Art and Artists I, 4 (1966): 47.
71 Marcel Duchamp, cited in Schwarz, The Complete Works of Marcel Duchamp, 466. For a transcript of the interview, see Otto Hahn, "Marcel Duchamp," I'Express (Paris) 684 (23 July 1964), 22-23.

72 Camfield, "Marcel Duchamp's Fountain," 79-81.

73 Mina I.oy, no citle, The Blind Man 2 (May 1917): 12.

74 Ancliff, Anarchist Modernism, 9).

75 In an interview with Francis Roberts, Duchamp stated that the readymade has "a philosophical side to it. The de-deifying of the artist. (Of lowering his status in society." Roberts, "I Propose to Strain the Laws of Physics," 47.

76 Alfred Krcymborg, Troubadour: an Autobiography (New York, 1925), 210.

77 Kreymborg, Iroubadour, 263-64.

78 Robert Alden Sanborn, "A Champion in the Wilderness," Broom III (October 1922): 179.

79 Coady, "Cosmopsychographical Organization," The Soil I, 1: following 30. The statement "What does 2.91 mean to you" refers to an issue of Camera Work that explored the theme "What does '291' Mean?" See Camera Work 47 (July 1914).

80 The final sentence in the caption contains threc quotations: "And, besides, 'we guarantee these pictures'- 'in so far as honest expert opinion can guarantee anything' although 'it is obviously impossible to guarantee anything which does not, as yet, exist." The two latter quotations are from Willard Huntington Wright's responses in the New York Sun to Coady's questions regarding whether the Forum Exhibition committee could guarantee the "pcrmanent market valuc" of the paintings. As discussed in note 15 , Wright responded that the aim of the Forum Exhibition was not to promote the sale of art for commercial purposes. "Current News of Art and the Exhibitions," New York Sun, 12 March 1916, 8.

81 Antliff, Anarchist Modernism, 32-33.

82 Marius de Zayas to Alfred Stieglitz, 26 and 27 May 1914, reprinted in Marius de Zayas, How, When, and Why Modern Art Came to New York, cd. Francis M. Naumann (Cambridgc, 1996), 170; and Pepe Karmcl, "Pablo Picasso and Georges Braquc, 1914-1915: Skeletons of Thought," Modern Art and America: Alfred Stieglitz and his New York Galleries, ed. Sarah Greenough (Boston, 2000), 185-86, 504nn3-4. Stieglitz did manage to circumvent the exclusive arrangement Kahnweiler had with the Washington Square Gallery by borrowing paintings by Picasso and Braque from his friend Francis Picabia and exhibiting them at 291. See Karmel, "Pablo Picasso and Georges Braque," 186.

83 Alfred Sticglit< to Marius de Zayas, 9 June 1914, reprinted in de Zayas, How, When, and Why Modern Art Came to New York, 174. In late 1916, Coady moved his Washington Square Gallery- renamed as Coady Gallery-to 489 Fifth Avenue, close to Stieglitz's offshoot of the 291 gallery, the Modern Gallery, which was located at 500 Fifth Avenue and managed by Marius de 7.ayas. See Zilczer, "Robert J. Coady, Man of The Soil," 37; and "'291' and the Modern Gallery," Camera Work 48 (October 1916): 63-64. The ad- 
vertisement for the Coady Gallery printed in The Soil iterated the gallery's commercial focus: "The Art Value and the Market Value of each Work Permanently Guaranteed." The Soil 1, 1: 55. man," 86 son to approach Stieglitz instead asking his friend Man Ray. Naumann, "Discussion," in de Duve, "Given the Richard Mutt Case," 234.

91 Naumann, New York Dada: 1915-23, 192-211.

92 See New York Dada (April 1921).

93 New York Dada, an anthology edited by Rudolf E. Kuenzli, includes an article by Judith Zilczer that aligns Coady with New York Dada. Kuenzli notes in the introduction that Coady "agreed with the Dada anti-art, a-art position." Rudolf E. Kuenzli, "Introduction," in New York Dada, cd. Rudolf E. Kuenzli (New York, 1986), 7; and Zilczer, "Robert J. Coady, Man of The Soil," 31-43. The eighth volume of Crisis and the Arts: the History of Dada focuses on New York Dada and contains an articlc by Ruth Bohan in which she suggests that Coady "shared many of its [Dada's] basic assumptions and operational strategies." Bohan, "Whitman's 'Barbaric Yawp,"' 35.$$
\text { tit }
$$

99

100 "Notre ami Caudy [sic] a disparu de la circultion [sic]." Marcel Duchamp to Jean Crotti and Suzanne Duchamp, 20 October 1920, Jean Crotti papers, Archives of American Art, Smithsonian Institution; English translation from Naumann, "Affectucuscment, Marcel: Ten Letters from Marcel Duchamp," 14.

101 Judith Zilczer and Ruth Bohan have also both made the assump- tion that Duchamp and Coady were friends, based on Duchamp's statement above. Zilczer, "Robert J. Coady, Man of The Soil," 42n28; and Bohan, "Whitman's 'Barbaric Yawp," 35. Crotti married Duchamp's sister Suzanne in April 1919. See Naumann, New York Dada: 1915-23, 104.

102 Corn, The Great American Thing, 49.

103 Corn, The Great American Thing, 56-57.

104 Corn. The Great American Thing, 69-75. I disagree with Corn's assumption that "Duchamp had been culturally primed to admire the luxury of the American bathroom and its glistening white appliances....And it is easy to imagine how futuristic a snow shovel of wood and galvanized iron hanging or stacked in multiples in a hardware store - the store itself a marvel to a foreigner-might appear to a Frenchman accustomed to streets swept of snow by brooms of straw or twigs whose design had changed little since the Middle Ages" (p. 71). 